\title{
Textural Features - Indicators of Pollution
}

\section{Leena Grace Beslin}

Department of Biotechnology, Gogate Jogalker College, Ratnagiri, Maharashtra, India

\begin{abstract}
The dynamic estuarine environment influences the sedimentary processes like physical and chemical characteristics of sediments. The dominant factor in sediment transport is the motion of water. The particles are moved by the current of water in the way of sliding, rolling, siltation and suspension. Texture a peculiar feature of the sediment which describes the nature of soil. In the water bodies, the textural characteristics reflect how long the sedimentary particles are affected by organic and inorganic contaminants. For the present study three different estuaries namely Kadinamkulam backwater, Veli Lake and Poonthura backwater around the Trivandrum city of Kerala were chosen as study sites. From each estuary three stations such as riverine zone, middle zone and bar mouth zone were fixed for collection of samples. Monthly collection of sediment for a period of one year from April-2014 to March 2015 was carried out. Regular analysis of texture was done and calculated the results. The observations from the present study showed that most of the months and in all the selected stations sandy soil dominates. The clayey and silty soil was reported in certain stations in specific seasons.
\end{abstract}

Keywords: Texture; Sediment; Sand; Silt; Clay; Estuary

\section{Introduction}

The sub-surface environment of the estuaries is highly heterogeneous in its composition. Very often, a subsurface is composed of layers of materials with vastly different properties such as sand, silt and clay. The composition may vary over distances of few centimetres, because fluids can move only through the pore spaces between the grains of sand. The sand openings are distributed scattered and their contaminant migration pathways are extremely difficult to predict. Fine grained bottom sediments are formed out of suspended material and have a composition that reflects the original suspended material with geochemical, biological and geological processes operating in the aquatic environment [1]. The nature of the backwater sediments changed with spatial and temporal variations in the percentage composition of sand, silt and clay fractions. Gravels and coarse sediments that show less organic matter are less contaminated unless they are in the vicinity of a source of effluent. The fine fractions of the organic content are due to the large surface area provided by clay fractions for the adsorption [2]. According to Geetha Bhadran high percentage of sand in the sediment shows that the site is well drained by water. Concentration of sand in relation to clay and silt serves to emphasize the range of soils, more specifically with respect to drainage.

\section{Materials and Methods}

Three different estuaries around Trivandrum city of Kerala state was selected for the collection of sediments. The estuaries were Kadinamkulam estuary, Veli lake and Poonthura backwater. From each estuary three different stations were located to get a accurate data of texture. The textural analysis of the sediment was carried out by adopting pipette method as described by Carver [3]. The various size fractions of the sediment were computed from their respective settling velocities of the sediment. The sediment textural characteristics were classified into three groups based on the size of the particles.

Viz. Clay $\rightarrow<4 \mu \mathrm{m}$, Silt $\rightarrow$ between $4 \mu \mathrm{m}$ and $63 \mu \mathrm{m}$ and Sand $\rightarrow$ $>63 \mu \mathrm{m}$.

\section{Results}

The textural characteristics of the three selected estuaries were presented. The monthly distribution of the size of the particles in different stations on a percentage basis was illustrated in Tables 1-3. The textural study of the sediment revealed that in Kadinamkulam backwater the mean percentage composition of sand was 63.55 which ranged from 60.99 in station III to 67.73 in station II. The mean sand content of Veli Lake was $61.59 \%$ which ranged from $52.4 \%$ in station II to $74.63 \%$ in station I. In Poonthura the mean sand content was $53.85 \%$ which varied from $45.62 \%$ in station I to $59.55 \%$ in station III. The mean silt content of Kadinamkulam was $22.41 \%$ which ranged from $19.98 \%$ in station II to $24.73 \%$ in station I. The mean silt content of Veli was $23.02 \%$ which varied from $12.96 \%$ in station II to $29.46 \%$ in station I. In Poonthura, the mean silt content was $26.8 \%$ which ranged from $24.67 \%$ in station II to $29.54 \%$ in station III. The mean distribution of clay content was $14.43 \%$ in Kadinamkulam estuary which ranged from $16.49 \%$ in station III to $13.12 \%$ in station II. In Veli, the mean clay content was $15.17 \%$ which varied from $11.84 \%$ in station III to $21.23 \%$ in station I. The mean clay content of Poonthura backwater was $19.91 \%$ which ranged between $12.05 \%$ in station III and $28.13 \%$ in station I (Figures 1-3).

\section{Discussion}

The major textural class of the entire sediment contained coarse sand to very fine sand with negligible quantities of silt and clay. The marked difference seen between samples of different stations could be attributed to the difference in environmental conditions like waves, tides and river flow in the estuaries. The deposition of sandy sediments in the main channel area of estuaries was influenced by the sea and they get transported into the estuaries through the inlets by tidal waves [4]. The present study agrees the above findings that the marked difference seen between samples of different stations could be attributed to the

*Corresponding author: Leena Grace Beslin, Department of Biotechnology, Gogate Jogalker College, Ratnagiri-415 612, Maharashtra, India, Tel: 02227453820; E-mail: drblgrace@rediffmail.com

Received September 05, 2017; Accepted September 18, 2017; Published September 23, 2017

Citation: Beslin LG (2017) Textural Features - Indicators of Pollution. J Environ Anal Toxicol 7: 505. doi: 10.4172/2161-0525.1000505

Copyright: (c) 2017 Beslin LG. This is an open-access article distributed under the terms of the Creative Commons Attribution License, which permits unrestricted use, distribution, and reproduction in any medium, provided the original author and source are credited. 
Page 2 of 4

\begin{tabular}{|c|c|c|c|c|c|c|c|c|c|c|c|c|}
\hline MONTHS & \multicolumn{3}{|c|}{ STATION-I } & \multicolumn{3}{|c|}{ STATION-II } & \multicolumn{3}{c|}{ STATION-III } \\
\hline & sand & silt & clay & soil nature & sand & silt & clay & soil nature & sand & silt & clay & soil nature \\
\hline April (2014) & 56.22 & 29.98 & 13.80 & sandy & 63.88 & 17.32 & 18.80 & sandy & 60.35 & 11.45 & 28.20 & Sandy \\
\hline May & 59.65 & 24.83 & 15.82 & sandysilt & 67.33 & 18.23 & 14.44 & sandy & 62.74 & 21.74 & 15.52 & Sandysilt \\
\hline June & 70.32 & 14.10 & 15.58 & sandy & 71.02 & 20.10 & 8.88 & sandy & 76.22 & 4.90 & 18.88 & Sandy \\
\hline July & 88.14 & 1.42 & 10.44 & sandy & 80.83 & 6.93 & 12.24 & sandy & 83.85 & 2.83 & 13.32 & Sandy \\
\hline August & 71.65 & 19.51 & 8.84 & sandy & 76.25 & 12.53 & 11.22 & sandy & 40.52 & 40.66 & 18.82 & Siltysand \\
\hline September & 62.55 & 30.11 & 11.32 & sandy & 70.35 & 28.11 & 11.54 & sandy & 38.12 & 49.56 & 12.32 & Siltysand \\
\hline October & 62.32 & 26.80 & 10.88 & sandy & 68.56 & 20.50 & 10.94 & sandy & 43.22 & 45.46 & 11.32 & Siltysand \\
\hline November & 51.89 & 29.27 & 18.84 & sandysilt & 70.88 & 11.40 & 17.72 & sandy & 69.34 & 12.78 & 17.88 & Sandy \\
\hline December & 52.33 & 31.03 & 16.64 & sandy & 65.55 & 25.57 & 8.88 & sandy & 62.55 & 17.37 & 20.08 & Sandy \\
\hline January (2015) & 56.32 & 34.84 & 8.84 & sandy & 53.56 & 35.12 & 11.32 & sandysilt & 56.38 & 32.07 & 11.55 & Sandysilt \\
\hline February & 56.22 & 24.96 & 18.82 & sandy & 64.28 & 19.06 & 16.66 & sandy & 65.74 & 18.68 & 15.58 & Sandy \\
\hline March & 55.68 & 29.92 & 14.40 & sandy & 60.31 & 24.89 & 14.80 & sandy & 72.87 & 12.73 & 14.40 & Sandy \\
\hline
\end{tabular}

Table 1: Monthly distribution of particle size (\%) in sediments of Kadinamkulam backwater.

\begin{tabular}{|c|c|c|c|c|c|c|c|c|c|c|c|c|}
\hline MONTHS & \multicolumn{4}{|c|}{ STATION-I } & \multicolumn{3}{c|}{ STATION-II } & \multicolumn{3}{c|}{ STATION-III } \\
\hline & sand & silt & clay & soil nature & sand & silt & clay & soil nature & sand & silt & Clay & soil nature \\
\hline April (2014) & 65.70 & 18.50 & 15.80 & sandy & 62.20 & 24.40 & 13.40 & sandy & 55.62 & 35.58 & 8.80 & siltysand \\
\hline May & 72.30 & 11.02 & 16.68 & sandy & 64.40 & 25.68 & 9.92 & sandysilt & 56.98 & 41.46 & 1.56 & siltysand \\
\hline June & 62.55 & 33.01 & 4.44 & sandysilt & 50.58 & 40.54 & 8.88 & siltysand & 37.58 & 44.22 & 6.64 & siltysand \\
\hline July & 71.94 & 13.62 & 14.44 & sandy & 56.20 & 29.32 & 14.48 & sandysilt & 48.97 & 42.15 & 8.88 & siltysand \\
\hline August & 63.55 & 17.63 & 18.38 & sandy & 50.28 & 9.14 & 40.58 & sandy & 50.62 & 22.70 & 26.68 & sandy \\
\hline September & 72.58 & 14.87 & 12.55 & sandy & 65.58 & 17.77 & 16.65 & sandy & 68.32 & 13.90 & 17.78 & sandy \\
\hline October & 72.55 & 15.57 & 11.88 & sandy & 66.32 & 21.36 & 12.32 & sandy & 69.65 & 16.63 & 14.32 & sandy \\
\hline November & 83.36 & 4.32 & 12.32 & sandy & 53.05 & 39.15 & 12.80 & sandy & 49.56 & 36.00 & 14.44 & sandy \\
\hline December & 72.55 & 7.47 & 19.98 & sandy & 50.65 & 36.11 & 13.24 & sandysilt & 60.55 & 27.61 & 11.84 & sandysilt \\
\hline January (2015) & 78.55 & 9.57 & 11.88 & sandy & 43.22 & 44.23 & 12.55 & siltysand & 53.22 & 37.90 & 8.88 & sandysilt \\
\hline February & 88.42 & 2.98 & 8.88 & sandy & 55.22 & 25.96 & 18.82 & sandy & 67.55 & 25.81 & 6.64 & sandy \\
\hline March & 91.46 & 6.98 & 1.56 & sandy & 11.04 & 7.90 & 81.06 & sandy & 74.25 & 10.15 & 15.60 & sandy \\
\hline
\end{tabular}

Table 2: Monthly distribution of particle size (\%) in sediments of Veli Lake.

\begin{tabular}{|c|c|c|c|c|c|c|c|c|c|c|c|c|}
\hline MONTHS & \multicolumn{4}{|c|}{ STATION-I } & \multicolumn{3}{c|}{ STATION-II } & \multicolumn{4}{c|}{ STATION-III } \\
\hline & sand & silt & clay & soil nature & sand & silt & clay & soil nature & sand & silt & clay & soil nature \\
\hline April (2014) & 10.58 & 6.79 & 82.63 & clayey & 50.32 & 39.76 & 9.92 & sandysilt & 51.62 & 35.00 & 13.38 & sandysilt \\
\hline May & 65.32 & 18.68 & 16.00 & sandy & 56.98 & 1.46 & 41.56 & clayeysand & 56.80 & 42.32 & 14.48 & siltysandy \\
\hline June & 51.08 & 36.70 & 12.22 & sandysilt & 53.94 & 27.18 & 18.88 & sandysilt & 50.82 & 39.20 & 9.98 & sandysilt \\
\hline July & 61.03 & 20.09 & 18.88 & sandy & 71.12 & 18.84 & 10.04 & sandy & 60.36 & 30.76 & 8.88 & sandysilt \\
\hline August & 38.32 & 50.36 & 11.32 & siltysand & 56.22 & 30.46 & 13.32 & sandysilt & 60.22 & 20.90 & 18.88 & sandy \\
\hline September & 68.55 & 12.58 & 18.87 & sandy & 56.22 & 20.90 & 22.88 & sandy & 48.22 & 26.90 & 24.88 & sandy \\
\hline October & 9.65 & 8.03 & 82.32 & clayey & 56.32 & 33.12 & 10.56 & sandysilt & 52.33 & 36.79 & 10.88 & sandysilt \\
\hline November & 35.41 & 50.95 & 13.64 & siltysand & 59.87 & 28.65 & 11.48 & sandysilt & 73.50 & 16.18 & 10.32 & sandy \\
\hline December & 35.32 & 36.34 & 28.34 & siltysand & 50.32 & 21.36 & 28.32 & clayeysand & 56.22 & 40.90 & 2.88 & sandysilt \\
\hline January (2015) & 19.88 & 56.90 & 23.22 & silty & 56.32 & 9.46 & 34.22 & sandyclay & 50.32 & 40.80 & 8.88 & sandysilt \\
\hline February & 67.22 & 13.84 & 18.94 & sandy & 56.28 & 32.38 & 11.34 & sandysilt & 76.22 & 13.94 & 9.84 & sandy \\
\hline March & 85.05 & 3.83 & 11.12 & sandy & 52.65 & 25.23 & 22.12 & sandysilt & 77.94 & 10.78 & 11.28 & sandy \\
\hline
\end{tabular}

Table 3: Monthly distribution of particle size (\%) in sediments of poonthura backwater. 


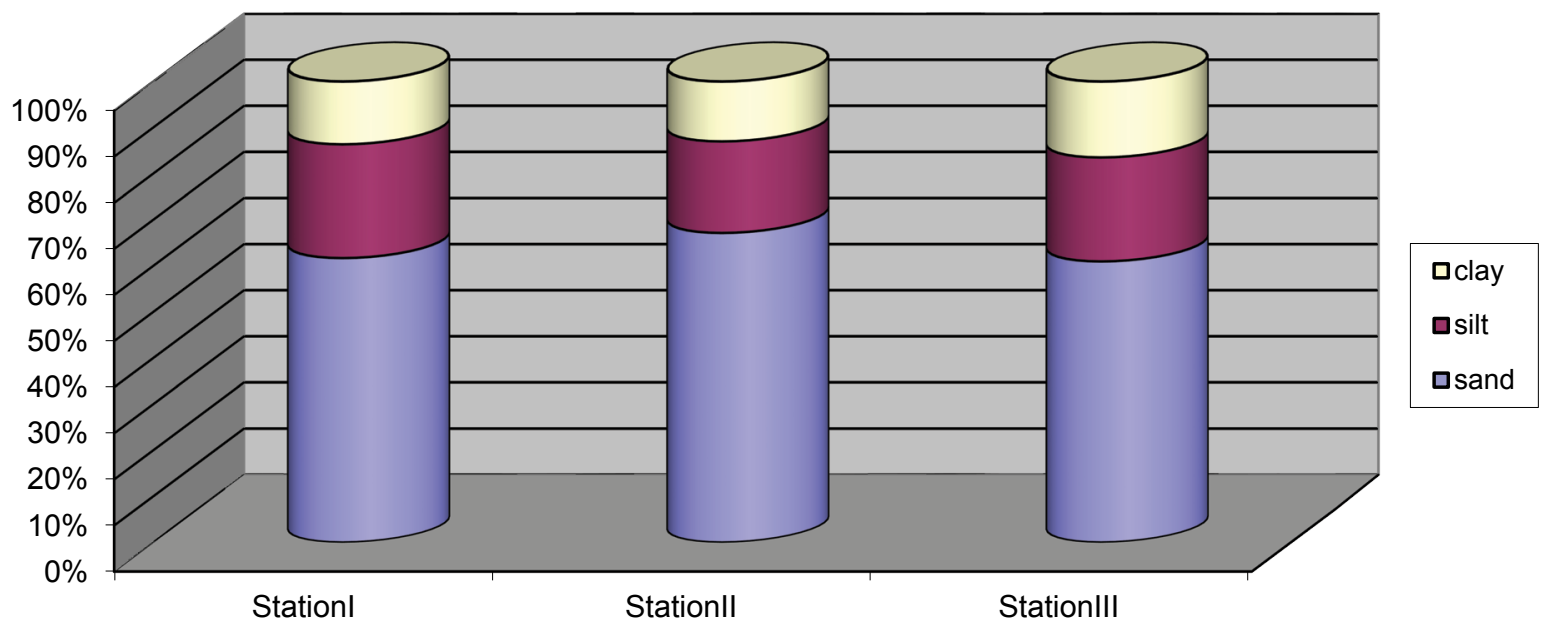

Figure 1: Cylindrical bar showing monthly mean distribution of sand,silt and clay in Kadinamkulam backwater.

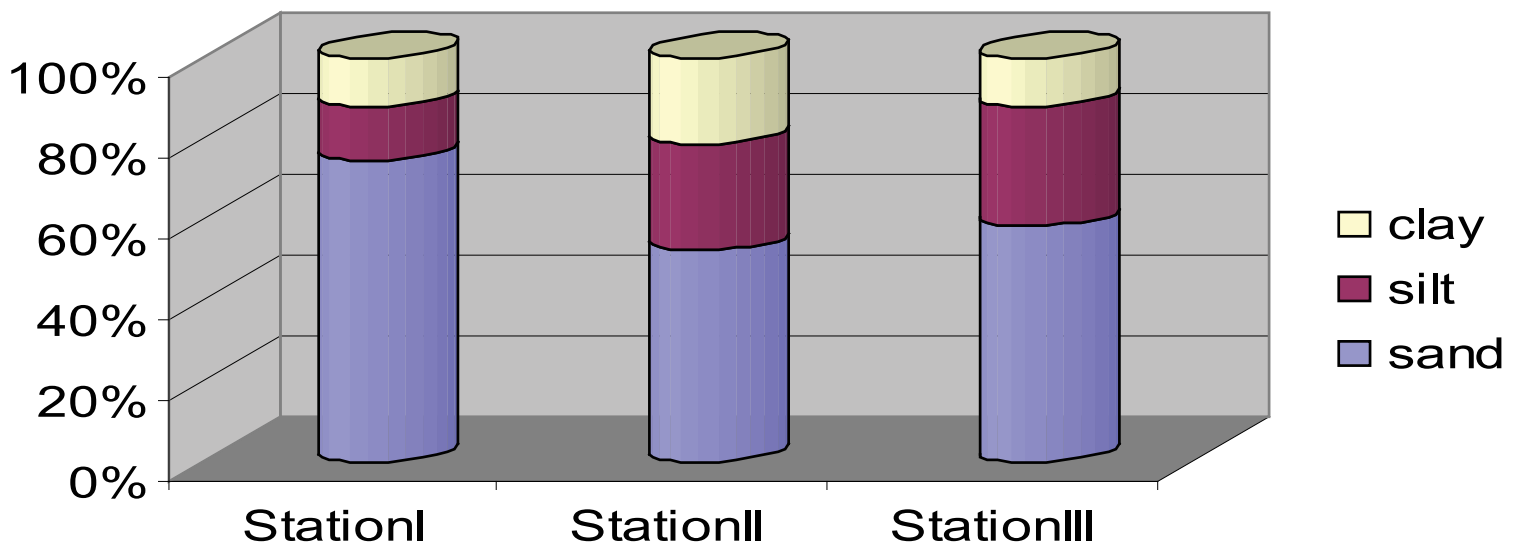

Figure 2: Cylindrical bar showing mean distribution of sand silt and clay in the sediments of veli lake.

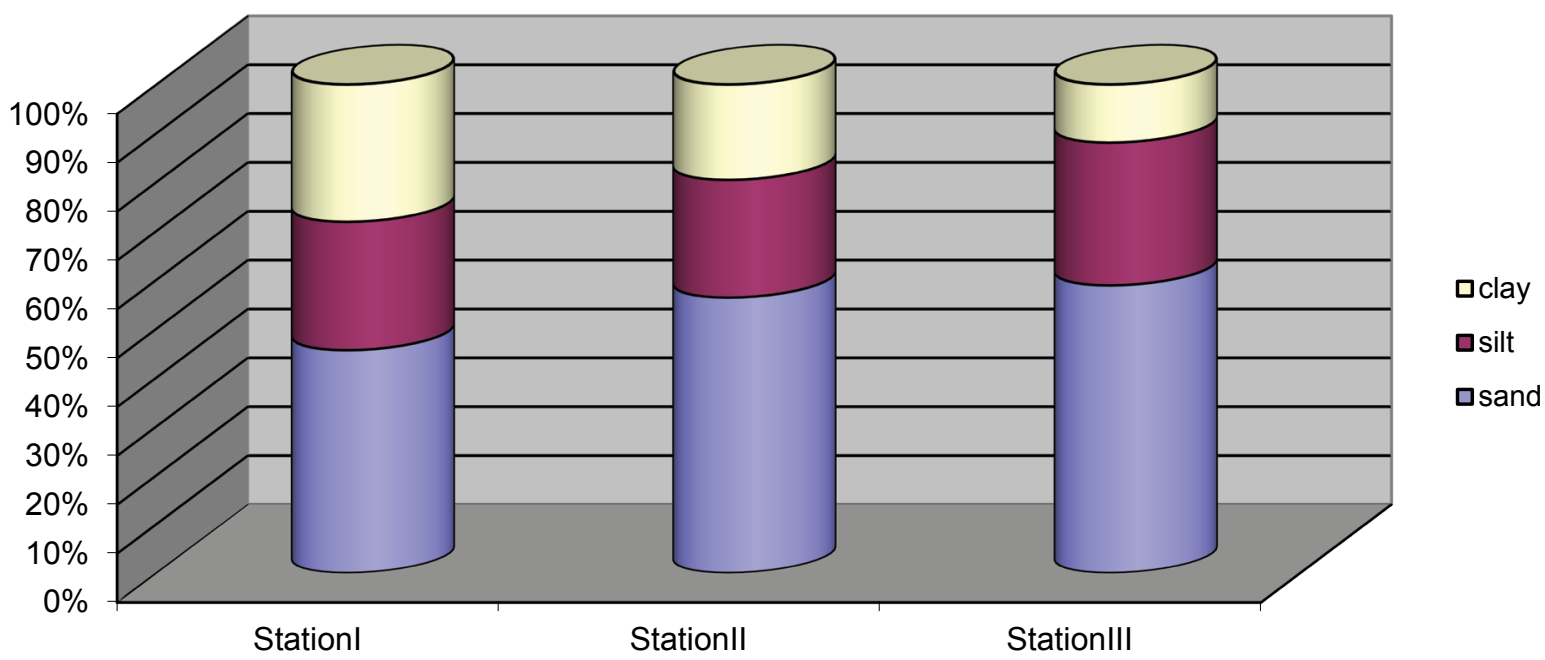

Figure 3: Cylindrical bar showing monthly mean distribution of sand, silt and clay in Poonthura backwater. 
difference in environmental conditions like oscillation of waves, tidal influx and river flow in the three estuaries. The textural properties of the present study revealed that even though the sandy material dominated throughout the year, the clay and silt content were represented more in certain months especially in Poonthura backwaters. Kumary et al. [5] reported that of Poonthura estuary with higher percentage of finer particles at the sheltered upstream stations. Generally there exists a gradation towards finer materials form the mouth of the estuary due to reduced flow, deposition of fine mud and tidal flow during different seasons. Seetharamaiah and Swamy [6] stated that due to low velocity of the wave motion, the sand particles settled within a short distance from the point of their entry into the estuarine system. The area with a high percentage of clay is capable of having a high proportion of organic matter [7]. Organic matter content is greater in the samples where fine fractions predominate. This is due to the large surface area provided by clay fractions for adsorption [8]. From the present study, the textural properties of three estuaries with different stations revealed that the sandy soils having less pollutants like organic matter and heavy metals. The clayey and silty soils reflect more metals and other pollutants.

\section{References}

1. Eisma D (1995) Suspended matter in the aquatic environment. McGraw Hill Books, New York, p: 300

2. Das AK (2000) Role of physical and chemical features of soil in reservoir productivity. Fishing Chimes 20: 30-32.

3. Carver RE (1971) Sedimentary Petrology. John Wiley and Sons Inc., London, UK, p: 180.

4. Sahu BK, Pradhan BB, Mishra SB (2014) Texture and Grain-Size Parameters of Coastal Sediments of Chilka Lake. Indian J Mar Sci 19: 226-227.

5. Kumary KS, Azis PK, Natarajan P (2010) Sediment characteristics of Poonthura estuary (southwest coast of India) in relation to pollution. Indian J Mar Sci 30 $75-80$.

6. Seetharamaiah J, Swamy AS (1994) Texture of inner shelf sediments off Penner river, east coast of India. Indian J Mar Sci 23: 195-198.

7. Purandara BK, Dora YL (1987) Studies on the texture and Organic matter in the sediments of Vembanad lake near shore sediments. Proc. Nat. Sem. Estuarine Management, pp: 440-452.

8. Anirudhan TS, Achari S, George O (1991) Absorption and desorption of inorganic phosphorus by sediments of lake Veli, South-West Coast of India. J Appl Hydro 4: 17-28. 